\title{
УКД 613.6/616.9-036:621:001.5
}

\section{CУЧACHI ПPОБАЕМИ САHITAPHO-

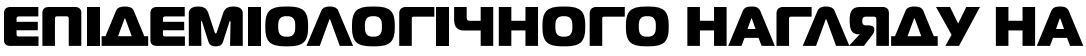 ПIАПРИЕМСТВАХ МАШИНОБУАУВАННЯ}

\section{Кононова I.г.}

\section{Київська міська санітарно-епідеміологічна станшія}

Представлено матеріали щодо деяких аспектів санітарно-гігієнічного нагляду на підприємствах промисловості України, міста Київ та машинобудування, зокрема. Наведено дані про структуру підконтрольних об'єктів машинобудування та чисельності працюючих у шкідливих та небезпечних умовах праці на них. Визначена кількість профзахворювань у галузі машинобудування в м. Київ.

Ключові слова: санітарно-епідеміологічний нагляд, дослідження факторів виробничого середовища,

Україна, м. Київ, підприємства галузі машинобудування

\section{Вступ}

Санітарно-епідеміологічний нагляд у промисловості має значну історію. Ще за радянських часів питанням профілактичних, оздоровчих та лікувальних заходів для зниження професійної захворюваності на промислових підприємствах приділялася значна увага. Проблеми організації державного санітарно-епідеміологічного нагляду, в тому числі на підприємствах машинобудування, висвітлювали в своїх роботах такі провідні діячі науки як академіки Кундієв Ю.І., Трахтенберг I.M., Ізмеров I.М., а також Шевченко А.М., Чабанова О.В. Коршун М.М, Тарасенко Н.Ю., Чернюк В.І., Гвозденко Л.А та інші [ $1-6]$.

За роки становлення України як незалежної держави, у період соціально-демографічних і економічних перетворень, реструктуризації великих промислових підприємств, появи нових форм власності, і розвитку ринкових відносин, змін у медичному обслуговуванні працюючих відбулися потреби в зміні організації санітарно-гігієнічного нагляду за промисловими підприємствами. На сучасному рівні діяльність санітарного-лікаря з гігієни праці на підприємстві неможливо розглядати тільки як наглядову. Поточний нагляд на підприємствах, який здійснюеться на підставі поглибленого аналізу умов праці, повинен органічно поєднуватися з вивченням стану здоров'я, працездатності,професійної та професійно-обумовленої захворюваності і завершуватися розробкою спрямованих оздоровчих заходів.

Водночас в умовах економічної, екологічної та демографічної кризи в структурі населення країни спостерігаються руйнівні тенденції, що призводять до скорочення трудового потенціалу. На жаль, сучасна державна політика направлена не на заходи для збе- реження здоров'я, а на компенсацію втрати здоров'я за рахунок не завжди адекватних пільг та надбавок.

Практично зруйнована система розробки та реального впровадження національних та регіональних програм із питань покращання гігієни та охорони праці на робочих місцях. Мета дослідження наукове обгрунтування гігієнічних заходів щодо збереження здоров'я працюючих та удосконалення санітарно-епідеміологічного нагляду за підприємствами машинобудування.

\section{Матеріали та методи дослідження}

Аналіз стану умов праці та кількості працюючих, у тому числі працюючих зі шкідливими та небезпечними факторами виробничого середовища та трудового процесу на підприємствах різних форм власності проводився за даними річних «Звітів про фактори навколишнього середовища, що впливають на стан здоров'я людини» форма 18, що затверджена наказом МОЗ України 03.05.1999 № 102, по санепідустановах м. Қиїв та України, а також статистичних даних Держкомстату України [9, 10, 11, 12].

Використано методи системного аналізу, гігієнічних та епідеміологічних досліджень, медичної статистики.

Предметом дослідження є річні звіти та особисті дослідження щодо результатів роботи санепідустанов міста; протоколи лабораторних та інструментальних досліджень факторів виробничого середовища та трудового процесу на робочих місцях (районних СЕС, міської СЕС ); звіти та карти обліку професійного захворювання (отруєння); інформаційні довідки щодо санітарно-епідеміологічної ситуації щодо умов праці на підприемствах галузі в м. Київ та в Україні. 


\section{Результати дослідження та їх обговорення}

Державним санітарно - епідеміологічний наглядом та вирішенням проблем профілактики професійних та професійно обумовлених захворювань 3 оцінкою впливу факторів виробничого середовища на здоров’я працюючих у структурі санепідслужби міста Київ займаються відділення гігієни праці 10 районних та міської санепідстанцій. Чисельність фактично працюючих у відділеннях гігієни праці в 2008 році становила 59 працівників, з них 26 лікарів, 2 інженери, 29 помічників та 1 технік.

Чисельність робітників та службовців у місті на підконтрольних об'єктах нагляду на 01.01.2009 року становила 932447 , тобто на 17,5 тисяч менше ніж у минулому році. Кількість працюючих, зайнятих на підприємствах, в установах та в організаціях, що займаються виробничою діяльністю (за даними районних СЕС на 01.01.2009 р.), становить 450671 (2007 рік - 462320, 2006 рік. - 485051), у тому числі 154167 (2007 рік - 156290) жінок. Кількість об'ектів нагляду, з урахуванням зниклих та нових, до колишнього року мала тенденцію до зниження (2004 рік - 3721, 2005 рік - 3739, 2006 рік 3757, 2007 рік - 3714). На обліку знаходиться 3826 об’єктів контролю. Цю ситуацію можливо пояснити зменшенням кількості великих підприемств та створенням на їх базі дрібних, переважно недержавної форми власності.

Промисловий потенціал міста поступово скорочується. Передбачити, як складеться ситуація в умовах економічної кризи, достатньо важко. Разом із тим, кількість працюючих в шкідливих та небезпечних умовах праці від усіх працюючих практично залишається на рівні минулих років.

Протягом 2008 року санітарно-епідеміологічні станції отримали для виконання та використання в роботі декілька документів, що вносять розбіжності в оцінку ризику об'єктів, зокрема, промислових підприемств. Це постанова Головного державного санітарного лікаря № 8 від 14.02.2008 року « Про розподіл об'єктів державного нагляду за ступенем ризику» та Постанова ҚМУ від 10.09.2008 року № 843 «Про затвердження критерію, за яким оцінюється ступінь ризику від впровадження діяльності в сфері охорони здоров'я для безпеки життя і здоров'я населення та визначається періодичність здійснення планових заходів державного нагляду (контролю)».

Критерієм по оцінці групи ризику згідно цих документів для підприємств $є$ клас небезпеки разом із визначенням санітарно-захисної зони відповідно ДСП 173-06 «Державні санітарні правила плану- вання та забудови населених місць». При цьому, при застосуванні даних критеріїв не враховувалися факти наявності порушень санітарних нормативів у робочій зоні, наявність професійних та професійно обумовлених захворювань, а також наявність інших виробничих шкідливих факторів різних класів умов праці за Гігієнічною класифікацією праці за показниками шкідливості та небезпечності факторів виробничого середовища, важкості та напруженості трудового процесу ГН 3.3.5-3.3.846.6.1-083-2001 (8). Крім того, є певні розбіжності у визначенні групи ризику виробництв лікарських засобів та об’єктів, де $є$ поводження з наркотичними засобами, психотропними речовинами та прекурсорами. Існуючі розбіжності та нечіткості в різних документах не дозволили якісно провести аналіз по промислових підприємствах за критеріями ризику та порівняти об’єкти по групах ризику з минулими роками.

На теперішній час відмова від принципів переважного медичного обслуговування працюючого населення призвела до майже повної ліквідації медичних установ цільового призначення. За останні роки ліквідовано 5 медсанчастин і $30 \%$ усіх здоровпунктів. Частина колишніх медсанчастин перетворилася в незалежні приватні медичні комплекси, що не мають зацікавленості в профілактичній роботі з постійно зростаючою групою ризику.

За для успішної розробки та впровадження оздоровчих заходів вкрай необхідна комплексність фахівців санепідстанції, лікувально-профілактичних закладів, служб охорони праці та керівників підприемств.

Практично не залишилося на підприємствах посади відомчих санітарних лікарів, які безпосередньо щоденно повинні були вирішувати питання гігієни праці на кожному робочому місці. У місті Київ на теперішній час залишилося 2 санітарно-промислових лікаря. Кожен рік скорочуються кількість санітарно-промислових лабораторій підприємств, задача яких є постійний лабораторний та інструментальний контроль шкідливих факторів виробничого середовища. Ще декілька років тому на підприємствах Києва було біля 40 таких лабораторій, зараз іх залишилося 18.

Проведений аналіз стану умов праці в Україні та в Києві, зокрема, свідчить, що жодна галузь промисловості не може вважатися повністю безпечною. За даними Держкомстату України кожний четвертий $(27,5 \%)$ працює в умовах, які не відповідають санітарним нормам за параметрами виробничих факторів. Декілька років тому в таких умовах працював кожен шостий робітник. 
Tабілич 1

Показники діяльності державного санітарно-епідеміологічного нагляду на промислових підприємствах м. Київ у динаміці за 2004-2008 роки

\begin{tabular}{|l|c|c|c|c|c|}
\hline \multicolumn{1}{|r|}{ Роки } & $\mathbf{2 0 0 4}$ & $\mathbf{2 0 0 5}$ & $\mathbf{2 0 0 6}$ & $\mathbf{2 0 0 7}$ & $\mathbf{2 0 0 8}$ \\
\hline $\begin{array}{l}\text { Показник } \\
\text { діяльності }\end{array}$ & 6346 & 6293 & 6144 & 5598 & 5331 \\
\hline Кількість обстежень всього & 108,6 & 106,6 & 105,9 & 103,7 & 100,5 \\
\hline $\begin{array}{l}\text { Кількість обстежень на 1 фахівця } \\
\text { відділення гігієни праці }\end{array}$ & 3605 & 3201 & 2956 & 2971 & 2863 \\
\hline $\begin{array}{l}\text { Кількість обстежень із виявленими } \\
\text { порушеннями }\end{array}$ & 1092 & 1124 & 1186 & 2193 & 1365 \\
\hline $\begin{array}{l}\text { Кількість обстежень із залученням } \\
\text { лабораторій СЕС }\end{array}$ & 738 & 835 & 858 & 1001 & 1058 \\
\hline $\begin{array}{l}\text { Кількість об‘єктів, обстежених із } \\
\text { лабораторними й інструментальними } \\
\text { дослідженнями }\end{array}$
\end{tabular}

На теперішній час проходить постійних процес структурних змін у реєстрі промислових підприємств, збільшується кількість малих підприемств приватної та колективної форми власності. Зараз у місті Київ усього 63275 малих підприємств, з них 6474 в промисловості. На 10 тисяч населення в Україні припадає 70 малих підприємств, а в м. Київ 232. Усього по Україні в 2007 році зареєстровано 324000 малих підприемств, з них у місті Київ 63300.

За останні 5 років у місті Қиїв продовжує збільшуватися кількість працівників, що мають шкідли ві та небезпечні умови праці: 2003 рік - 97736 (20\% ), 2004 рік - 103502 (21\%), 2005 рік $104305(21,8 \%), 2006$ рік - $110702(22,9 \%)$, 2007 рік - 107699 (23,3 \% ), 2008 рік- 107607 (23,9 \% від усіх працюючих). Відбуваються також зміни в проведенні державного санітарного нагляду, а саме зменшується кількість обстежень, у тому числі обстежень на 1 фахівця відділення, а також кількість обстежень із застосуваннями лабораторних і інструментальних методів досліджень та обстежень із виявленими порушеннями санітарних норм та правил. Разом із тим є тенденція до збіль- шення кількості об'єктів нагляду на яких проводилися лабораторні дослідження (табл.1).

Машинобудування - найважливіша комплексна галузь обробної промисловості, що включає в себе верстатобудування, приладобудування, енергетичне, металургійне, хімічне та сільськогосподарське машинобудування. До цієї галузі прийнято відносити також електротехнічну промисловість, радіоелектричну і транспортне машинобудування всіх видів. Традиційно машинобудування поділяють на наступні групи - важке, загальне, середне, точне, виробництво металевих виробів та заготовок, ремонт машини і встаткування. Основним елементом розвитку сучасного машинобудування є вдосконалення засобів виробництва, методів організації, перехід до стандартизації, автоматизації і інформаційного забезпечення. Кількість промислових підприємств в Україні за видами діяльності наведено в табл. 2.

Серед промислових підприємств державної форми власності в м. Қиїв найбільша частина припадає на об'єкти загального машинобудування, а саме підприємства авіаційної промисловості, суднобудування. Крім того, є підприємства верстатобудування, різнопланова інструментальна промисловість,

Кількість підприємств у промисловості та машинобудуванні в Україні

\begin{tabular}{|l|c|c|}
\hline \multicolumn{1}{|c|}{ Види діяльності } & \multicolumn{2}{|c|}{ Роки спостереження } \\
\cline { 2 - 3 } & \multicolumn{2}{|c|}{$\mathbf{2 0 0 1}$} \\
\hline Промисловість & 47348 & 54925 \\
\hline Машинобудування & 10345 & 11073 \\
\hline у тому числі & 4842 \\
\hline виробництво машин та встаткування & 4471 & 5085 \\
\hline виробництво електротехнічного та електронного устаткування & 1032 & 4847 \\
\hline виробництво транспортних засобів та устаткування & 1141 \\
\hline
\end{tabular}


промисловість побутових приладів і машин. До того же досить значна група підприємств точного машинобудування, а саме підприемства приладобудування, де виготовлюють оптичні прилади, радіоелектронну апаратуру, авіаційні прилади, годинники. У більшості випадків підприємства приладобудування в місті Київ представлені підприємствами військово - промислового комплексу. У світовому виробництві суден питома вага України в 1995 році складала 0,8 \%, а вже в 1998 році впала до 0,3\%. $\mathrm{Y}$ місті Київ цей напрямок представлено ВАТ «Завод Ленінська кузня», який є одним із найбільш ризиковим по професійних захворюваннях. Одним з основних та провідних підприємств у галузі авіабудування є КиДАЗ «Авіант» разом з АНТК ім. Антонова, що зараз проходять етап об'єднання.

За даними аналізу серед підприємств державних форм управління галузь машинобудування в місті Київ представлена 44 підприемствами та організаціями, які на теперішній час працюють. Серед них 3 підприємства відносяться до важкого машинобудування, 5 - до суднобудування, 11 - оборонне машинобудування, 3 - автомобільне й 22 - приладобудування. Біля 10 підприємств фактично припинили свою виробничу діяльність, і залишилися тільки як орендодавці. 348257 працюючих у шкідливих та небезпечних умовах праці зайнято 20,1% (9701 робітник). Серед підприємств галузі державної форми власності тільки 2 можливо віднести до 1 групи ризику, тобто небезпечні з позиції санітарного законодавства.
До цієї ж галузі можливо віднести й 41 підприємство $з$ недержавною формою власності. Розподіл підприємств недержавної форми власності за видами машинобудування провести на даному етапі неможливо. Кількість працюючих на них значно нища, і становить 2898 робітників, з яких тільки 930 виконують роботу в умовах впливу шкідливих та небезпечних виробничих факторів, що становить $32,1 \%$. Достовірність цих даних досить відносна в зв'язку з тим, що постійного моніторингу приватні роботодавці практично не проводять, зміна технологічних процесів відбувається частіше ніж можливість вибіркових санітарно-гігієнічних досліджень по державному контролю. Крім того, на більшості з них відсутні фахівці з охорони праці й атестація проводиться в кращому випадку раз на п'ять років.

Машинобудування - це галузь, де визначається в різних рівнях комплекс практично всіх шкідливих та небезпечних факторів виробничого процесу та трудового середовища. Неможливо визначити підприємство галузі без технологічних процесів де немає шуму, вібрації, компонентів зварювального аерозолю, несприятливого мікроклімату, різних видів пилу і токсичних хімічних речовин різного класу небезпеки. У деяких технологічних процесах присутній такий фактор, як неіонізуюче випромінювання.

Дані щодо кількості працюючих в умовах, що не відповідають нормативним по факторах виробничо го процесу, представлено в табл. 3.

Аналіз результатів досліджень хімічних факторів виробничого середовища за 2008 рік на підприємствах

Кількість працюючих в умовах, що не відповідають санітарно-гігієнічним нормам по окремих видах економічної діяльності

\begin{tabular}{|c|c|c|c|c|}
\hline \multirow{3}{*}{$\begin{array}{c}\text { Гігіснічний показник умов } \\
\text { праці }\end{array}$} & \multicolumn{4}{|c|}{ Кількість працюючих (в тис.) } \\
\hline & \multicolumn{3}{|c|}{ в Украӥні } & \multirow{2}{*}{$\begin{array}{c}\text { у м. Київ } \\
\text { усього }\end{array}$} \\
\hline & усього & у промисловості & у машинобудуванні & \\
\hline $\begin{array}{l}\text { Працівників - у невідповідних } \\
\text { санітарно -гігієнічних умовах }\end{array}$ & 1512,1 & 1161,4 & 68,6 & 61,8 \\
\hline \% до облікової кількості & 27,5 & 34,9 & 22 & 16,8 \\
\hline \multicolumn{5}{|l|}{3 них по факторах } \\
\hline шкідливі хімічні речовини & 9,3 & 12,6 & 11,1 & 4,8 \\
\hline фіброгенний пил & 10,2 & 15,0 & 8,4 & 2,4 \\
\hline вібрація & 3,4 & 3,8 & 2,2 & 1,9 \\
\hline шум & 14,0 & 19,0 & 12,1 & 8,1 \\
\hline несприятливий мікроклімат & 8,4 & 12,3 & 7,5 & 4,3 \\
\hline зовнішня температура & 3,2 & 3,0 & 0,7 & 2,4 \\
\hline важкість праці & 6,9 & 9,1 & 3,3 & 2,4 \\
\hline вимушена робоча поза & 9,8 & 12,0 & 7,1 & 5,7 \\
\hline напруженість праці & 9,1 & 10,8 & 4,1 & 4,2 \\
\hline інші фактори & 0,7 & 1,0 & 0,2 & 0,6 \\
\hline
\end{tabular}


Кількість уперше зареєстрованих хронічних профзахворювань на підприємствах машинобудування в м. Київ за 2004-2008 роки

\begin{tabular}{|l|c|c|c|c|c|}
\hline \multicolumn{1}{|l|}{ Роки } \\
$\begin{array}{l}\text { Підприємства } \\
\text { галузі }\end{array}$ & $\mathbf{2 0 0 4}$ & $\mathbf{2 0 0 5}$ & $\mathbf{2 0 0 6}$ & $\mathbf{2 0 0 7}$ & $\mathbf{2 0 0 8}$ \\
\hline Київ & $\mathbf{2 3}$ & $\mathbf{1 7}$ & $\mathbf{2 4}$ & $\mathbf{1 6}$ & $\mathbf{1 8}$ \\
\hline ВАТ «Завод Більшовик» & 6 & 2 & 5 & 2 & 4 \\
\hline КП «Київтрактородеталь» & 1 & 2 & 2 & 2 & 1 \\
\hline ВАТ Завод « Ленінська кузня» & 4 & 4 & 7 & 4 & 5 \\
\hline КиДАЗ «Авіант» & - & 2 & 1 & 2 & 2 \\
\hline Підприємства машинобудування в м. Київ & $\mathbf{1 1}$ & $\mathbf{1 0}$ & $\mathbf{1 5}$ & $\mathbf{1 0}$ & $\mathbf{1 2}$ \\
\hline $\begin{array}{l}\text { Доля профзахворювань у галузі } \\
\text { машинобудування від усіх випадків }\end{array}$ & 47,8 & 58,8 & 62,5 & 62,5 & 66,6 \\
\hline
\end{tabular}

машинобудування м. Київ 172 робочих місць виявив перевищення в 10,5%. При дослідженнях шумових характеристик перевищення гранично допустимих рівнів виявлено в 25 \% випадках. Відхилення показників мікроклімату виявлено в $40 \%$ випадків обстеження робочих місць.

Ураховуючи вище визначене, підстави для формування професійних ризиків на підприемствах галузі існують, що підтверджується даними наявності хронічної профзахворюваності в місті за період 2004-2008 роки (табл.4).

Таким чином, аналіз стану санітарно-епідеміологічного нагляду на підприємствах машинобудування свідчить про те, що це є складною соціально-гігієнічною проблемою, яка пов'язана із соціальнодемографічними та економічними перетворювання ми, реструктуризацією промислових підприємств, появою нових форм власності, зміною медичного обслуговування працюючих.

\section{Висновки}

1. За роки незалежності в структурі державної санепідслужби м. Қиїв зменшилася фактична чисельність працюючих лікарів, помічників та технічних фахівців у відділеннях гігієни праці.

\section{Литература}

1. Трахтенберг I.М. Гігієна праці та виробнича санітарія / I.M. Трахтенберг, М.М. Коршун, О.В. Чебанова.- К., 1997.- 462c.

2. Текущий санитарный надзор в промышленности и сельском хозяйстве /[ Чебанова О.В., Лащук Г.Н., Быстрова Л.Е. и др.].- К.: Здоровья, 1988.- 240с.

3. Руководство по гигиене труда. В 2-х томах/ под. ред. Измерова Н.Ф.- М.: Медицина, 1987.-368с.

4. Шевченко А.М., Борисенко Н.Ф., Пушкарь М.П. Санитарный надзор в промышленности / А.М. Шев-
Збільшується кількість об'єктів нагляду та кількість об'єктів обстежених із лабораторними методами досліджень.

2. На підприємствах машинобудування в м. Київ доля працюючих у шкідливих та небезпечних умовах праці становить 20,5%, з них на державних $20,1 \%$, на малих та приватних $-32,1 \%$.

3. Динаміка та повнота державного санепіднагляду за останні роки мають зміни: зменшується кількість обстежень, у тому числі обстежень на одного фахівця відділення, кількість обстежень із застосуваннями лабораторних і інструментальних методів досліджень, кількість обстежень із виявленими порушеннями санітарних норм та правил. Разом із тим, збільшується кількість часу для організаційних заходів для проведення обстежень та підготовки результатів.

4. Динаміка показників уперше зареєстрованих профзахворювань у м. Київ свідчить про їхнє зниження за останні 5 років на $28 \%$, що не відповідає дійсному стану, і не може служити реальним показником покращання умов праці на виробництві. Доля профзахворювань серед працівників галузі машинобудування значна і перевищує $66 \%$ від усіх уперше зареєстрованих випадків.

ченко, Н.Ф. Борисенко, М.П. Пушкарь.- К.: Здоровья, 1981.- 200с.

5. Гігієна праці: Підручник за редакцією А.М. Шевченка.- К.: Інфотекс, 2000.- С. 508-526.

6. Гігієна праці (Методи досліджень та санітарноепідеміологічний нагляд) - за редакцією А.М. Шевченка, О.П. Яворовського.- Вінниця : НОВА КНИГА, 2005.- $608 \mathrm{c}$.

7. Кундієв Ю.І. Професійне здоров’я в Україні : епідеміологічний аналіз / Ю.І. Кундієв, А.М. Нагорна.К.: Авіцена, 2006.- 316 с. 
8. Гігієнічна класифікація праці за показниками шкідливості та небезпечності факторів виробничого середовища, важкості та напруженості трудового процесу, 2001.

9. Статистичний збірник « Україна у цифрах 2007 р.».Консультант, 2008.- С. 62, 64, 113, 115.
10. Статистичний щорічник України за 2007 рік Держкомстату України.- 571 с.

11. Статистичний збірник "Економічна активність населення України 2007 р.».- К.,2008.- 224 с.

12. Статистичний збірник " Праця України 2007 р.».К.: Держкомстат України, 2008.- 406 с.

\section{Кононова И.Г.}

\section{СОВРЕМЕННЫЕ ПРОБАЕМЫ САНИТАРНО-ЭПИАЕМИОЛОГИЧОГО НААЗОРА НА ПРЕАПРИЯТИЯХ МАШИНОСТРОЕНИЯ}

\section{Киевская городская санитарно-эпимемиологическая станция}

Представлены материалы о состоянии некоторых аспектов санитарно- эпидемиологического надзора на промышленных предприятиях Украины, города Киев и отрасли машиностроения, в часности. Приведены данные о структуре подконтрольных объектов машиностроения и численности работающих, в том числе работающих во вредных и неблагоприятных условиях труда.

Проведен анализ состояния профзаболеваемости на предприятиях машиностроения в г.Киев.

Ключевые слова: санитарно-эпидемиологический надзор, исследование факторов производственной среды, Украина, город Киев, предприятия отрасли машиностроения

\section{Kononova I.G.}

\section{ACTUAL PROBLEMS OF SANITARY AND EPIDEMIOLOGICAL SUPERVISION AT MACHINE-BUILDING ENTERPRISES}

Kyiv City Sanitary and Epidemiological Station

The materials are presented concerning selected aspects of sanitary and hygienic supervision at industrial enterprises of the city Kyiv, in machine-building in particular. The data on the structure of the supervised subjects of the machine-building industry and on the number of individuals, working in harmful and dangerous conditions are laid down. The number of occupational diseases recorded in machine-building industry of the city Kyiv has been defined.

Key words: sanitary and epidemiological supervision, environmental factors, city Kyiv, machine-building enterprises

Надійшла: 07.09.2009

Контактна особа: Кононова І.Г., Київська міська санітарно-епідеміологічна станція, 10/8, вул. Некрасівська, м.Київ, 04053. Тел.: (44) 486-22-54. 